\title{
Digital society in the context of the COVID-19 pandemic: first results and prospects (comparative analysis of the experience of Russia and Bulgaria)
}

\section{Цифровое общество в контексте пандемии COVID-19: первые итоги и перспективы (сравнительный анализ опыта России и Болгарии)}

\author{
DOI: $10.12737 / 2587-6295-2020-80-89$ \\ UDC (УДК): 32.019 .51 \\ Received: 04.06.2020 Approved: 12.06.2020 Published: 25.06.2020
}

\begin{abstract}
Volodenkov S.V.
Doctor of Political Sciences, Associate Professor, Professor, Department of Public Policy, Faculty of Political Science, Moscow State University named after M.V. Lomonosov

e-mail: s.v.cyber@gmail.com
\end{abstract}

\section{Володенков С.В.}

д-р полит. наук, доцент, профессор, кафедра государственной политики факультета политологии Московского государственного университета имени М. В. Ломоносова e-mail: s.v.cyber@gmail.com

\section{Pastarmadzhieva D.D.}

Ph.D. in Political Sciences, Chief Assistant Professor, Department of Political Sciences and National Security, University of Plovdiv Paisii Hilendarski, Bulgaria

e-mail: daniela.pastarmadzhieva@uni-plovdiv.bg

Пастармаджиева Д.Д.

канд. полит. наук, главный ассистент профессора, кафедра политических наук и национальной безопасности, Пловдивский университет имени Паисия Хилендарского, Болгария

e-mail: daniela.pastarmadzhieva@uni-plovdiv.bg

\begin{abstract}
This work aims to study the peculiarities of digital society development in Russia and Bulgaria in the context of the COVID-19 pandemic. In order to solve this task the authors used a variety of methods, namely comparative analysis, critical analysis, and case-stage method. The article analyzes the experience of the socio-political processes of digitalization in Russia and Bulgaria in the context of the self-isolation regime formation in both countries. The authors put forward a hypothesis that both countries have found themselves in recent months in the conditions of forced digitalization, which has left its mark on the processes of the natural evolution of digital society. The results of the study give ground to conclude that forced digitalization lies mainly in the intensification and randomization of digital communication flows, but not in the qualitative development of a digital society and the emergence of new technological solutions that could contribute to effective and meaningful socio-political development. The practical significance of the work lies in the comprehension of the current processes of the socio-political sphere's digitalization and identifying key problems and challenges, without which it is impossible to successfully solve the problems of the transition of contemporary society to a new stage of its evolution in the digital environment.
\end{abstract}


Keywords: digital society, COVID-19, digital communications, Internet, social development, forced digitalization.

\section{Аннотация}

Целью настоящей работы является исследование особенностей развития цифрового общества в России и Болгарии в условиях пандемии COVID-19. Для решения данной задачи в рамках исследования были использованы методы компаративного анализа, критического анализа, а также метод кейс-стади. В статье проанализирован опыт цифровизации общественно-политических процессов России и Болгарии в контексте формирования режима самоизоляции в обеих странах. Авторы выдвигают гипотезу, заключающуюся в том, что обе страны оказались в последние месяцы в условиях вынужденной, форсированной цифровизации, что наложило свой отпечаток на процессы естественной эволюции цифрового общества. В работе делается вывод о том, что форсированная цифровизация заключается в большей степени в интенсификации и хаотизации потоков цифровой коммуникации, но не в качественном развитии цифрового общества и появлении новых технологических решений, которые могли бы способствовать эффективному и содержательному общественно-политическому развитию. Практическая значимость работы состоит в осмыслении актуальных процессов цифровизации общественно-политической сферы и выявлении ключевых проблем и вызовов, без учета которых невозможно успешное решение задач по переходу современного общества на новый этап своей эволюции в цифровой среде.

Ключевые слова: цифровое общество, COVID-19, цифровые коммуникации, Интернет, общественное развитие, форсированная цифровизация.

\section{Introduction}

Last decades were marked by rapid technological development, which created preconditions for the digitalization of almost every area of life. On one hand the process of digitalization have been unavoidable, but one the other this process have happened with very different intensity, depending on the will and capabilities of the governments, the companies and the individuals. In the context of the spread of the COVID-19 pandemic, most countries were forced to take measures related to the introduction of self-isolation regimes for the population. In Bulgaria the so called "state of emergency" started on 13 March 2020 [11] and a week later the big cities were put under a regim for for entering and leaving them [14]. However, the people were still allowed to go out of their homes, but just to buy medicines, groceries or go to work. In Russia, the regime of self-isolation was announced by the president of the country on March 30 . People over 65 years old were forbidden to go out, and for the rest of the population it was recommended to leave the house only to buy groceries at the nearest store, visit the nearest pharmacy and take out the garbage.

Obviously, under such conditions, a significant multiplicative effect of digitalization of various spheres of the state's and society's vital activity, including the socio-political area, arose. Traditional communicative interactions have been forced to give way to modern technologies of distant digital communication.

However, the health situation, caused by COVID-19 varies across countries. Furthermore, the measures also vary and the differences are due to two main factors - the point of taking measures and the intensity of the contagion. As concern the point of measures some countries relied on preventive measures and others on reactive ones. There was also a great variety in the number of infected persons per million. By 29 May in San Marino were confirmed 20334 cases per million and in Lesotho and Papua New Guinea less than one person per million people. We divided the countries in six groups according to the number of confirmed cases and the results are presented in table 1. 
Table 1. Grouping of the country according to the number of confirmed cases, 29 May 2020

\begin{tabular}{|l|l|l|l|l|l|l|}
\hline Cases & $\begin{array}{l}\text { Over } \\
\mathbf{1 0 0 0 0}\end{array}$ & $\begin{array}{l}\mathbf{5 0 0 0 -} \\
\mathbf{1 0 0 0 0}\end{array}$ & $\mathbf{1 0 0 0 - 4 9 9 9}$ & $\mathbf{5 0 0 - 9 9 9}$ & $\mathbf{1 0 0 - 4 9 9}$ & $\mathbf{1 - 9 9}$ \\
\hline Countries & 2 & 10 & 46 & 21 & 66 & 53 \\
\hline
\end{tabular}

Source: World Health Organization and the World Bank ${ }^{1}[21 ; 22]$

By 29 May in Russia there were 2683 cases per million people, which puts the country on $30^{\text {th }}$ place out of 198 studied countrie as the first country is the one with most cases. Thus Russia is in the third group from Table 1. Bulgaria is on $89^{\text {th }}$ place with 354 confirmed cases per million people and is in $5^{\text {th }}$ group. This gives us the possibility to examine the effects of digitalizaition in countries with different levels of spread of the disease and alongside the measures taken were different.

In this regard, the purpose of the study is to identify and analyze the features of society's digitalization in the current conditions of self-isolation. In order to achieve the purpose, we seek to find answers of the following research quesions:

1) What are the substantive, structural, and functional changes in the functioning processes of modern society in the context of its digitalization during the period of a viral pandemic?

2) What are the medium and long-term socio-political consequences of the digitalization of the life of modern society?

3) What are the main threats, risks, and challenges in the field of social development related to the digitalization of socio-political processes?

4) What is the potential of digital politics technologies in the system of modern public administration?

As a research hypothesis, the authors put forward the thesis that forced digitalization of the sphere of sociopolitical communications was not able to qualitatively replace the natural evolution of a digital society, offering intensification of digital communication flows instead of substantively new technological solutions, as well as reinforcing previously existing concerns about the possibilities of digital control over society on the part of technologically developed states and corporations.

To what extent the digitalization state's digitalization approach for the political, economic and social spheres of life will be successful in the future, how much society and government institutions will form effective "digital habits and skills," abandoning the traditional environment of social communication? Precise answers to such question can be given only in the postepidemiological period. Nevertheless, even today we can make many observations and conclusions that have the scientific potential for further research on the results, consequences, and prospects of digitalization of our society.

\section{Review of the scientific literature}

The studies, focused on the digitalization of societies demonstrate the transformation of spread of technologies in life. At the beginning of the new century the digital sphere was associated more with "leisure hours, community networks and personal lifestyles" [12]. Nowadays, twenty years later the digitalization is no more related only to personal activities and the digital sphere is not a supportive tool to our daily routines. It became an essential element of the structure of the latter and covers new areas in a more binding manner.

Alongside the question of the uneven distribution of network access across the countries and the social stratification withing countries was discussed [12]. Although the access to hardware, softare and networke have increased significantly during the last two decades similar issues are

\footnotetext{
${ }^{1}$ The numbers are calculated by the authors on the basis of data from the Situation Report - 130 of the World Health Organization on the total number of confirmed cases and the data on the total population from the World Bank. The most recent data was of 2018.
} 
object of concern nowadays. The digital disparities continue to be rather visible in certain regions and the countries' level of digitalization may vary.

Furthermore, within countries there is also a trend of uneven distribution of technologies, knowledge and will for digitalization. The diversities shouldn't be accepted but rather action must be taken to overcome them as the process of digitalization require inclusion. This should be regarded as responsibility of both the government and the civil society [5]. The topic of digital inequalities is an important factor, which we believe is relevant for the evaluation of the current situation under the challenges of the emergency situation and self isolation.

Another aspect that should be beared in mind is the manner in which the digitalization happens. It is obvious that we are witnessing various changes in the socio-political environment, which are tightly connected to the digitalization. Although these changes have happened rapidly they to high extent have been introduced smoothly and are not that visible to all society members. Bunz calls it a "silent revolution" as on one hand it have changed deeply the society and on the other the process sometimes even may not be intentional [3]. In this context as a result of the digitalization of the society the idea of digital citizenship occurs. But how the digital citizenship correspond to the traditional understanding of the citizenship. The latter is related to abilities and in particular "the ability to participate in society online" and to the frequency of internet use [10].

The mentioned topics have become even more relevant in the context of the new challenges, faced by the societies in the beginning of 2020. The COVID-19 pandemic and the self-isolation measures have raised many questions on the digital issues as the digital environment have increased its significance. To date, several studies have already appeared devoted to the study of digitalization of the socio-political sphere in the context of the COVID-19 pandemic. And in many of them sound very alarming forecasts, regarding the consequences of such digitalization. Wherein researchers consider a vast range of aspects of the problem.

For example, several researchers have suggested that "we are dealing with a huge emphasis on countering the strengthening of social ties (which are natural for natural disasters) - and on supporting the deepening and consolidation of extreme atomization." As M. A. Lepsky writes, emphasizing individualization and atomization as a relevant public practice, "the destruction of sociality leads to the movement of social activity online, people in isolation move life to the hyper-reality of social networks" [8].

At the same time, experts point out that digital communications have intensified the flow of rumors and misinformation that undermine socio-political stability in societies [4]. As speaking at the Munich Security Conference on February 15, 2020, WHO Director-General Tedros Adhan Ghebreesus said, "We are not just fighting the epidemic; we are fighting infodemia" [19]. Such topics require reaction not only from the societies but from the governments as well and the approaches in this area and the public reactions can help us understand the processes within the states.

Other scholars express concern over the growing potential for the formation of a regime of digital totalitarianism, within the framework of which symptoms such as "the totality of control over humanity with the help of "smart systems" become characteristic; people with limited mobility sitting in their apartments; the presence of special passes of various categories for movement" [1]. In many respects, experts in the field of public administration are in solidarity with them. So, for example, the Minister of Digital Development of the Russian Federation Konstantin Noskov publicly declared the threat of "digital totalitarianism": "Of course, there are such threats. They scare me very much. But if we are talking about such digital totalitarianism ... Soviet totalitarianism and Stalinism immediately come to mind, but in general, not only the state can become such a digital monopoly... Today, Google or Facebook as corporations are building "digital totalitarianism," but already not nationwide, but worldwide" [7].

In general, we can note that, according to many scientists, today, the traditional social, political, and economic systems of states go through what we can consider as a stress test, which has a significant number of vectors. 


\section{Methods}

In the framework of this study, we used the case study method to study real programs and approaches to digitalization in Russia and Bulgaria, the critical analysis method to objectively study the effectiveness of steps taken by states and corporations in the field of digitalization of the socio-political sphere and to identify problems associated with digitalization processes in the context of the COVID-19 pandemic, as well as a method of comparative analysis, which allowed us to identify the general and special in digitalization processes at the level of Russia and Bulgaria, to obtain a more detailed and volumetric picture of the events taking place in different countries.

\section{Results}

The extraordinary situation created by COVID-19 pandemic forced the states, the companies and the society to digitalize some of their routines and search for new approaches for work, communication and lifestyle. The states have had to provide more digital services for the business and citizens, the companies (where possible) have had to start working in the digital environment and the citizens were forced to intensify their usage of internet for communication. One of the areas had to adapt very rapidly and this is the area of education. The protection of the health of the population forced the governments to close the educational institutions and digitalize the education. We believe that such process require preparation in three key areas developing digital skills of teachers, developing the digital skills of students and provision of ICTs (including hardware, software and network). Ofcourse there have been neither the time, nor the resources for such preparation. Thus, the diversity in the digital resources for education led to an uneven educational process across the countries and within the countries.

Furthermore, in our opinion, the results of the digitalization processes analysis in the context of the COVID-19 pandemic demonstrate that the digital technologies potential has not been used at the moment with a sufficiently high degree of efficiency. Positive expectations in this area have largely not been met. It is primarily because, in recent months, the scale and intensity of the use of existing digital solutions in the field of socio-political interaction, economic and social spheres were mainly multiplied due to the sharply increased mass demand for services to meet the needs in these areas of the modern state's functioning. In other words, mass demand provoked a corresponding increase in supply, but no more.

The digitalization of the socio-political sphere has developed in recent months, in fact, not along the natural evolutionary path, but in an accelerated regime of forced self-isolation.

This circumstance has led to the fact that we do not observe qualitative digital breakthroughs. Instead, on the contrary, at some point, the scale of the massive use of digital technologies began to affect the functionality of Russian and foreign digital infrastructure. For example, most global providers of video content such as Netflix, Hulu, Apple TV, Disney +, YouTube have limited the quality of broadcast video content. Facebook and Instagram also lowered the parameters of the broadcast video content due to the high load on the communication infrastructure.

Russia was no exception. Almost immediately after the introduction of the self-isolation regime, residents of large Russian cities had difficulties with access to video hosting. MTS President Alexey Kornya even asked subscribers not to overload the mobile operator's network unnecessarily, since the load on digital mobile communication channels has increased dramatically [20]. In Bulgaria the initial increase of internet usage also caused changellenges and unexpected interruptions of the internet connections. However, such cases happened only at the very beginning of the self-isolation and the problems were solved very fast so that no intervention was required.

After a statement by Russian President Vladimir Putin on payments to families with children under 16 years old, the electronic government services portal also became virtually unavailable for several days due to overloading user requests. In an emergency, the service would have been merely useless, since it would not have allowed solving the problems of citizens quickly. And we 
can give a lot of such examples. The measures of Bulgarian government have been more focused on the business rather than families. Furthermore, the potential beneficieries are lesser and respectively the potential users of Government web portal. Even when the government introduced one of the most attractive measures for gratuitos support for SMEs the online platform didn't have challenges. According to the vice prime minister Tomislav Donchev at the peak of submitting application there were 30000 active users at the same time and the system managed to handle them [13]. It should be mentioned that the Bulgarian state didn't introduce measures to support most or all of the families and thus the system didn't face the challenge to be overloaded. Only few groups were able to benefit and some of the measures are related to banks and thus the people have had to turn to them and not to use e-government platforms.

As an analysis of current practice shows, the potential of digital resources and the digital infrastructure as a whole turned out to be limited in terms of the uninterrupted satisfaction of increased "digital needs" of citizens.

Did we get new digital mechanics and solutions in conditions of self-isolation? It seems to us that the answer to this question is mostly negative. In fact, the leading players did not offer us qualitatively new solutions that allow us not only to consume content actively but to build truly effective social communication in the digital space. We repeat that, in our opinion, today, we can only talk about the intensification of information and communication flows, but not about the transition to a qualitatively new level of the social structure of society, which, in theory, should be accompanied by digitalization.

In our opinion, one can hardly understand digitalization as an exclusively increase in the consumption of digital content. It seems to us that in this case, it makes sense to talk about the need for the formation of a new type of social ties, the transition to new models of digital sociopolitical communication, a reassessment of the role of government institutions and a review of the requirements for them. However, new structural digital connections of a social and sociopolitical type have not yet appeared. The examination of the actions of the Russian and the Bulgarian authorities show that these observations apply for both countries.

In fact, today, we are in a rather deadlock situation. The society is forced to be in a regime of self-isolation and this increases the consumption of digital content; information and communication activity of citizens is rising; the number of socio-political rumors and fakes spread in the digital space is growing (it is no coincidence that some experts pay special attention to the fact that digitalization not only helped to establish social connections but rather served as a catalyst for the viral spread of panic and misinformation in the social media space [4]); the state seeks to counteract the dissemination of harmful information by using specialized power structures; Internet sources, depending on their political commitment, present various versions of the assessment of events and the steps taken by the authorities to eliminate the epidemiological threat; in the space of social media, traditional discussions are formed.

As an attempt to confront the fake news at the beginning of the pandemic in Bulgaria, on 19 March 2020 one of the coalition partners in the Government (political party VMRO) introduced a bill against the fake news. They suggested measures against the "misinformation in the Internet environment". The latter was defined as ,dissemination through social networks, Internet sites or otherwise in the Internet environment through websites accessible from the territory of the Republic of Bulgaria, of a publication that contains false information concerning individuals or legal entities“" [23]. However, this idea didn't come to realization as the president excercised his constitutional veto power against this regulation, because there was no clear definition of "false information". The parliament agreed with the president's veto [15]. On 28 May VMRO again tried to introduce such bill but it was rejected by the MPs [17].

In this regard, it seems to us that there isn't a significant transformation under COVID-19 pandemic and we are observing a very standard picture of the functioning of the Internet, but only in a more intense and chaotic mode. The window of opportunity for the dissemination of new digital practices, in our opinion, was practically not used. The remark of M. A. Lepsky that "information civilization showed the unwillingness to work in most medical institutions to 
prevent and promote the necessary measures in the main channels of mass communication" [8] seems quite symptomatic.

The digitalization in the context of COVID-19 have raised the topic about the balance between the state intervention in people's private space and their basic right. In March 2020 there was an information that Google and Facebook negotiate with the American government to provide data about the location of their users to fight COVID-19 [16]. Bulgarian government also initiated similar measures although Bulgarians were never limited in leaving their homes. However, one of the measures in the Emergency State Act was the authorities to have the right to identify the location of the people under quarantine through their mobile phones. Such provision raised discussion and disagreement among people and it was confronted by the Bulgarian Socialist Party, which filed a complaint before the Constitutional court [18]. Currently, the case is ongoing.

Nevertheless, the use of SMS-informing technologies about leaving home, QR codes to receive passes fundamentally does not change anything, because these are standard technologies with their vulnerabilities and bottlenecks. These technologies can only facilitate the exercise of control over the movement of citizens; however, in the social aspect, they do not bring anything new. Digital socialization of people does not occur; social relations of a new type are not formed. New models of digital socio-political development are not offered to citizens.

At the same time, the organization of social services aimed at adapting citizens (primarily older people) to the digital space leaves much to be desired. In this area, attention is again drawn to the use of standard and even largely obsolete communication technologies. But what will be the effect of such decisions?

As mentioned above the education is a specific area and in order to support schools and university to finish their school year smoothly the digital environment have had to welcome educational activites in the context of self isolation. In Bulgaria in recent years there have been attempt to introduce e-journals for the schools. Almost $80 \%$ of the schools in Bulgaria in $2019 / 2020$ school year use e-journals. Some of them (about 20\%) use only them, while other combine the traditional with the digital form [9]. This novelty supported the work in the schools of Bulgaria durng the self-isolation period, but as the e-journal platform (www.shkolo.bg) wasn't ready for providing a whole range of services, needed for studying online, other platforms were also used. These were Microsoft Teams, Google Classroom, Zoom, etc. Ofcourse, there are schools, teachers and students, who don't posses the required equipment (hardware, software and network) and skills in order to participate in the online education. Thus, in Bulgaria as late as 1 May the government provided budget for ensuring interner access for places, where they don't have such [2].

The situation in the universities in Bulgarian have been similar, but their level of digitalization and readiness for online education vary significantly. From 25 April to 6 May four Bulgarian research institutions conducted a survey across university professors and student on the digital education. The results show that most of the students identify some positive effect of the online education. However, they share the opinion that it is good as a additional supportive tool but it can't replace the traditional form of education. The students see as good practice the online upload of additional educational resources, but alongside they don't like being limited in the communication due to the lack of live contact, the limited opportunities for feedback and informal communication, both between students and teachers, and between the students themselves [6].

The experience with the education shows that today we are not observing the synergy of digital platforms, technologies, and services that could be described as a transition to a new digital society. Most of the big digital services came up with independent, disparate, unconnected initiatives, not jointed in the common system (this mostly repeats the situation with internal disunity, attempts to develop their national models for counteracting the spread of the virus, refusing attempts through the UN General Assembly to abandon sanctions to reduce the negative effect from a pandemic in the field of economics). 
In many ways, it seems to us that the situation with the COVID-19 pandemic is perceived by the subjects of political, economic, and social activities of most states as purely temporary, requiring intensification of work until the end of the self-isolation regime.

The issue of the need for a sustainable transition to a qualitatively new digital format of the state's and society's life is not even on the list. It seems to us that neither the civil society itself, nor the institutions of power, nor the subjects of economic activity are ready for such a transition, and the idea of digitalization today is not provided with ready-made conceptual and functional solutions at the system level.

\section{Conclusions}

There are no contradictions on the existence of a digital space for socio-political communications, digitalization of the economy, processes of management, administration and control. Nonetheless, the formation of a digital social and socio-political space is yet to be done and the digitalization under COVID-19 proves it. It seems to us that without creating this kind of digital social space that allows not only satisfying the needs remotely but also creating stable social connections, generating social meanings, values, norms, it is impossible to solve the problem of transition to a digital society successfully. According to our forecasts, in the near future, it would be utopian to talk about effective digitalization even on the scale of one state.

Of course, we can predict the inevitable emergence of new technological solutions, services, products, and tools in the digital sphere based on an analysis of the current situation. However, a high-quality digital transition is impossible without systematic work to form a full-fledged digital society based on the synergistic effect, which could be characterized by the presence of a stable and full-fledged social interaction between citizens and between state and political institutions and public institutions, as well as common digital values, meanings, models of socially approved behavior, supported by relevant practices. Such environment can't be created while there is a diversity in the possession of sufficient technologies (hardware, software and network) by the companies and the individuals. Furthermore, a certain level of digital skills are required in order for inclusive digitalization. Such process need active involvement of the state and not only by creating policies and strategies, but also ensuring funds for their implementation. Such fundung is needed for the provision of technologies, where needed. Alongside, it is also needed for improving the digital competencies through learning in schools and universities, but also through life long learning.

Besides, one cannot take into account one significant circumstance - human thinking itself still has an analog nature. And this fact must be taken into account when analyzing the possibilities and prospects of digitalization in the near future. In Bulgaria during the emergency situation it was hard to stop people walking freely around and from the first they after the measures were cancelled people started seeing each other in cafes and parks as if nothing have happened. It seems that the latter have resisted silently to the process of digitalization as they simply have refused to be part of it in one way or another. A lot of people don't recognize the digital environment as preferred place for communication or at least they don't recognize it as the dominating one.

The first results from Russia and Bulgaria on the digitalization of societies under COVID-19 show that there is an intensification of use of digital tools, but it is perceived as a temporary measure and not as a new type of communication. Thus, we can conclude that there is some kind of quantitative transformation, but not a qualitative one.

\section{References}

1. Abramov A.V., Bagdasaryan V.E., Byshok S.O., Volodenkov S.V., Evstaf'ev D.G., Egorov V.G., Komleva N.A., Kramarenko N.S., Manoilo A.V., Mikhailenok O.M., Petrenko A.I., Prokof'ev V.F. Pandemia COVID-19: The end of the familiar world? Bulletin of Moscow Region State University (e-journal). 2020, V. 2, pp. 1-81. DOI: 10.18384/2224-0209-2020-21001. (In Russian). 
2. Bulgarian National Television. MON otpuska 1,6 mln. lv., za da imat uchenitsite dostap do internet [The Ministry of Education and Science allocates BGN 1.6 million so that students have access to the Internet] Available at: https://news.bnt.bg/news/mon-otpuska-16-mln-lv-zada-imat-uchenicite-dostap-do-internet-1052227news.html (Accessed: 28.05.2020).

3. Bunz M. The Silent Revolution. How Digitalization Transforms Knowledge, Work, Journalism and Politics Without Making Too Much Noise, UK, Palgrave Macmillan UK Publ., 2014, 134 p. DOI: 10.1057/9781137373502.

4. Depoux A., Martin S., Karafillakis E., Preet R., Wilder-Smith A., Larson H. The pandemic of social media panic travels faster than the COVID-19 outbreak. Journal of Travel Medicine. 2020, V. 27, I. 3, pp. 1-2. DOI: 10.1093/jtm/taaa031.

5. George B., Paul J. (2020) Digital Transformation in Business and Society. Theory and Cases, Springer International Publishing. Palgrave Macmillan Publ., 2020, 300 p. DOI: 10.1007/978-3-030-08277-2.

6. Getova A. (2020) Problemi i predizvikatelstva pred distantsionnoto obuchenie po vreme na izvanredno polozhenie. Analiz na rezultatite ot pilotno izsledvane za distantsionnoto obuchenie sred studenti na SU i NSA i sred prepodavateli ot SU (april-may 2020 g.) [Problems and challenges for distance learning during a state of emergency. Analysis of the results of a pilot study for distance learning among students of Sofia University and National Sports Academy and among teachers from Sofia University (April - May 2020)] Available at: http://phls.uni-sofia.bg/documents/articles/3052/DOKLAD_Prouchvane-na-distancionnotooburchenie-v-SU_2020.pdf (Accessed: 28.05.2020).

7. Kommersant. Glavu Minkomsvyazi pugaet «cifrovoj totalitarizm» Google i Facebook [The head of the Ministry of Communications fears the "digital totalitarianism" of Google and Facebook] Available at: https://www.kommersant.ru/doc/3825960 (Accessed: 28.05.2020). (In Russian).

8. Lepsky M.A. Sociological observation of a pandemic: connectedness, panic, crisis waves. Scientific Journal "Newsletter on the results of scholarly work in sociology, criminology, philosophy and political science”. 2020, V. 1, I. 1, pp. 46-59.

9. Monitor. Vsyako peto uchilishte prati v istoriyata hartienia dnevnik [Every fifth school sends the paper diary into the history] Available at: https://www.monitor.bg/bg/a/view/vsjakopeto-uchilishte-prati-v-istorijata-hartienija-dnevnik-temata-188898 (Accessed: 28.05.2020).

10. Mossberger K., Tolbert C.J., McNeal R.S. Digital Citizenship. The Internet, Society, and Participation. The MIT Press Publ., 2007, 240 p.

11. National Assembly of the Republic of Bulgaria. The Parliament declared a nationwide state of emergency from 13 March to 13 April 2020. Available at: https://www.parliament.bg/en/news/ID/5051 (Accessed: 28.05.2020).

12. Norris P. Digital Divide. Civic Engagement, Information Poverty, and the Internet Worldwide. Cambridge: Cambridge University Press Publ., 2001, 320 p. DOI: 10.1017/CBO9781139164887.

13. Nova. Nad 16500 sa podadenite zayavlenia za pomosht za malkite i sredni predpriyatia [More than 16,500 aid applications have been submitted by small and medium-sized enterprises] Available at: https:/nova.bg/news/view/2020/05/15/288030/над-16-500-са-подаденитезаявления-за-помощ-за-малките-и-средни-предприятия-видео/ (Accessed: 28.05.2020).

14. Nova. Zatvaryat oblastnite gradove, shte se minava prez KPP-ta [The regional cities are being closed, people will pass through the checkpoints] Available at: https://nova.bg/news/view/2020/03/20/282149/затварят-областните-градове-ще-се-минавапрез-кпп-та-обзор/ (Accessed: 29.05.2020).

15. Offnews. Parlamentat prie vetoto. Ninova: Kade otidoha 5 miliarda? Prazen li e rezervat? [The Parliament agreed with the veto. Ninova: Where did 5 billion go? Is the reserve empty?] Available at: https://m.offnews.bg/news/Politika_8/Parlamentat-prie-vetoto-Ninova-Kadeotidoha-5-miliarda-Prazen-li-e_724691.html (Accessed: 28.05.2020). 
16. Sheng E. Facebook, Google discuss sharing smartphone data with government to fight coronavirus, but there are risks. $C N B C$. Available at: https://www.cnbc.com/2020/03/19/facebook-google-could-share-smartphone-data-to-fightcoronavirus.html (Accessed: 28.05.2020).

17. Spasov Sv. Zakonat za falshivite novini na VMRO katastrofira. [The VMRO's fake news law crashed]. Sega. Available at: https://segabg.com/node/137160 (Accessed: 28.05.2020).

18. Stoyanov, M. BSP shte sezira Konstitutsionnia sad za prosledyavaneto na telefonite [BSP will refer to the Constitutional Court on the phone tracking]. Dnevnik. Available at: https://www.dnevnik.bg/bulgaria/2020/03/27/4047243_bsp_shte_sezira_konstitucionniia_sud_za /\#comments (Accessed: 28.05.2020).

19. The Lancet. COVID-19: fighting panic with information. The Lancet. 2020, V. 395, I. 10224, p. 537. DOI: 10.1016/S0140-6736(20)30379-2.

20. Vedomosti. Prezident MTS prizval abonentov k osoznannomu potrebleniyu internettrafika [MTS President urged subscribers to consciously consume Internet traffic] Available at: https://www.vedomosti.ru/technology/news/2020/03/26/826365-mts-prizval-sokratitpotreblenie-internet-trafika (Accessed: 28.05.2020). (In Russian).

21. World Bank. Population, total. Available at https://data.worldbank.org/indicator/SP.POP.TOTL (Accessed: 29.05.2020).

22. World Health Organization. Situation Report - 130. Available at: https://www.who.int/docs/default-source/coronaviruse/situation-reports/20200529-covid-19sitrep-130.pdf?sfvrsn=bf7e7f0c_4 (Accessed: 29.05.2020).

23. Zakon za izmenenie i dopalnenie na Zakona za radioto i televiziyata [Law for amendment and supplement of the Law for the radio and television]. Available at: https://www.parliament.bg/bills/44/054-01-25.pdf (Accessed: 28.05.2020). 